\title{
Perbedaan Pengaruh Terapi Bermain Mewarnai Gambar dengan Bermain Puzzle Terhadap Kecemasan Anak Usia Prasekolah di IRNA Anak RSUP Dr.M.Djamil Padang
}

\author{
Elza Sri Pratiwi ${ }^{a}$, Deswita ${ }^{a}$ \\ ${ }^{a}$ Fakultas Keperawatan Universitas Andalas \\ E-mail:Zha_Ragil@yahoo.com
}

\begin{abstract}
Illness and hospitalization are stressors that cause anxiety in children. The non-pharmacological management such as coloring pictures and play puzzle can be an alternative to reduce the anxiety. The purpose of this study was to determine differences in anxiety scores in hospitalized preschool children before and after coloring pictures and play puzzles. This study used a quasi-experimental design with non-equivalent comparison group pretest-posttest design, with 30 respondents sepatarated in two groups. Data collected using questionnaires. The results showed that there were significant differences in anxiety scores decreased in both groups $(p=0.010 /<\alpha)$, and coloring pictures reduce more anxiety scores compared with puzzle play (mean difference $=5.93$ points). The conclusion of this resesearch showed that both coloring pictures and play puzzle therapy can reduce anxiety scores. Play therapy coloring pictures better than the puzzle play therapy in reducing anxiety scores. It is recommended to health care institutions to improve health care for children again by giving therapeutic preschool coloring pictures to play especially on a regular basis to reduce anxiety in preschool children.
\end{abstract}

Key words: anxiety, preschool, coloring pictures, puzzle

\begin{abstract}
Abstrak: Kondisi sakit dan hospitalisasi merupakan stressor yang menyebabkan kecemasan pada anak. Penatalaksanaan secara non farmakologi seperti terapi bermain mewarnai gambar dan bermain puzzle dapat menjadi alternatif untuk menurunkan kecemasan tersebut. Tujuan penelitian ini untuk mengetahui perbedaan skor kecemasan pada anak prasekolah yang dirawat di rumah sakit sebelum dan sesudah diberikan terapi bermain mewarnai gambar dengan bermain puzzle. Penelitian ini menggunakan desain quasi eksperimen dengan pendekatan Non Equivalen Comparison Group Pretest-Posttest terhadap 30 responden yang terdiri dari 2 grup. Pengumpulan data dilakukan dengan menggunakan kuesioner. Terdapat perbedaan bermakna penurunan skor kecemasan pada kedua kelompok $(\mathrm{p}=0.010 /<\alpha)$, dan mewarnai gambar dapat menurunkan skor kecemasan lebih baik dibandingkan dengan bermain puzzle (dengan perbedaan rata-rata=5.93poin). Dapat disimpulkan bahwa terapi bermain mewarnai gambar dan terapi bermain puzzle dapat menurunkan skor kecemasan. Terapi bermain mewarnai gambar lebih baik dibandingkan dengan terapi bermain puzzle dalam menurunkan skor kecemasan. Disarankan kepada institusi pelayanan kesehatan untuk dapat meningkatkan lagi pelayanan kesehatan terhadap anak prasekolah dengan memberikan terapi bermain terutama mewarnai gambar secara teratur untuk mengurangi kecemasan pada anak prasekolah.
\end{abstract}

Kata kunci: kecemasan, anak prasekolah, mewarnai gambar, puzzle 


\section{PENDAHULUAN}

Hospitalisasi adalah suatu proses karena suatu alasan yang berencana atau darurat, mengharuskan anak untuk tinggal di rumah sakit, menjalani terapi dan perawatan sampai pemulangannya kembali ke rumah. Anak yang sakit dan harus dirawat di rumah sakit akan mengalami masa sulit karena tidak dapat melakukan kebiasaan seperti biasanya. Lingkungan dan orang-orang asing, perawatan dan berbagai prosedur yang dijalani oleh anak merupakan sumber utama cemas, terutama untuk anak yang pertama kali dirawat di rumah sakit (Nelson, 2000).

Penelitian yang dilakukan oleh psikolog dalam 30 tahun terakhir, menyebutkan bahwa 10-30 \% dari anakanak dengan hospitalisasi menderita gangguan psikologi dan sebanyak 90\% anak-anak merasa kecewa dan putus asa karena dirawat di rumah sakit. The Nasional Centre for Health Statistic memperkirakan bahwa 3-5 juta anak dibawah usia 15 tahun menjalani hospitalisasi setiap tahun. Saat anak-anak dirawat di rumah sakit, mereka cenderung merasa ditinggalkan oleh keluarganya dan merasa didalam lingkungan yang asing (Severo, 2009 dalam Wijayanti 2009). Angka kesakitan anak di Indonesia yang dirawat di rumah sakit cukup tingggi yaitu sekitar 35 per 100 anak, yang ditunjukan dengan selalu penuhnya ruangan anak baik rumah sakit pemerintah maupun rumah sakit swasta (Sumaryoko, 2008 dalam Wijayanti 2009).

Berbagai dampak kecemasan akibat hospitalisasi yang dialami oleh anak usia prasekolah, akan beresiko mengganggu tumbuh kembang anak dan berdampak pada proses penyembuhan. Kecemasan yang teratasi dengan cepat dan baik akan membuat anak lebih nyaman dan lebih kooperatif dengan tenaga medis sehingga tidak menghambat proses perawatan. Jika kecemasan itu berlangsung lama dan tidak teratasi maka akan menimbulkan reaksi kekecewaan pada orang tua yang menimbulkan sikap pelepasan pada anak sehingga anak mulai tidak peduli dengan ketidakhadiran orang tuanya dan lebih memilih untuk berdiam diri (apatis), menolak untuk diberikan tindakan dan yang paling parah akan menimbulkan trauma pada anak setelah keluar dari rumah sakit (Wong, 2008). Untuk itu dengan terapi bermain dan kerja sama orang tua yang baik dapat meminimalkan atau menurunkan kecemasan anak selama dirawat (Adriana, 2011).

Bermain adalah pekerjaan anak-anak disemua usia dan berperan penting dalam perkembangan mereka. Bermain juga merupakan aktivitas yang menyenangkan bagi anak dan salah satu alat paling penting untuk menatalaksanakan kecemasan akibat hospitalisasi menimbulkan krisis dalam kehidupan anak, dan karena situasi tersebut sering disertai cemas berlebihan, maka anakanak perlu bermain untuk mengeluarkan rasa takut dan cemas yang mereka alami sebagai alat koping dalam menghadapi stress. Bermain sangat penting bagi mental, emosional dan kesejahteraan anak seperti kebutuhan perkembangan dan kebutuhan bermain tidak juga terhenti pada saat anak sakit atau dirawat anak di rumah sakit (Wong, 2008).

Tujuan menerapkan terapi bermain pada anak di rumah sakit adalah agar anak dapat melanjutkan tumbuh kembang yang normal selama perawatan, agar dapat mengekspresikan pikiran dan fantasi anak, agar anak dapat mengembangkan kreatifitas melalui pengalaman bermain yang tepat dan agar anak dapat beradaptasi secara efektif dengan lingkungan yang baru yaitu rumah sakit sehingga kecemasan anak karena hospitalisasi dapat berkurang karena terapi bermain tersebut (Adriana, 2011). Selain itu terapi bermain akan melepaskan anak dari ketegangan dan kecemasan yang dialami. Karena dengan bermain anak akan dapat mangalihkan rasa sakitnya pada permainan (distraksi) dan relaksasi melalui kesenangannya dalam bermain. Akibat adanya distraksi dan relaksasi yang terjadi, anak yang mengalami cemas akhirnya menjadi tidak cemas lagi (Supartini, 2004).

Bermain pada masa prasekolah adalah kegiatan yang merupakan bagian penting dalam perkembangan pada tahun-tahun 
pertama masa kanak-kanak. Melalui bermain, anak dapat menunjukkan apa yang dirasakannya selama hospitalisasi karena dengan melakukan permainan anak dapat melupakan rasa sakitnya. Pertimbangan seperti karakteristik dan kebutuhan bermain anak usia prasekolah selama hospitalisasi, keterbatasan pasien anak untuk mobilisasi, biaya, ruangan khusus dan tenaga perawat yang terbatas, bermain dengan mewarnai dapat menjadi pilihan untuk membantu mengurangi kecemasan anak (Wong, 2008). Bermain puzzle juga merupakan salah satu terapi bermain yang merupakan aktifitas yang sangat sesuai dengan perkembangan emosi anak. Puzzle dapat meningkatkan daya pikir anak dan konsentrasi anak. Melalui puzzle anak akan dapat mempelajari sesuatu yg rumit serta anak akan berpikir bagaimana puzzle dapat tersusun dengan rapi.

Berdasarkan hasil studi pendahuluan yang dilakukan pada tanggal 27 februari 2013, bahwa 7 dari 10 orang anak yang dirawat di ruang anak RSUD Dr.M.Djamil Padang mengalami kecemasan, dengan reaksi kecemasan yang rata-rata sama seperti 7 orang anak tidak mau dirawat dirumah sakit, 5 orang anak sering menangis, menolak makan dan 7 orang anak sering meminta pulang karena merasa takut dengan orang asing (tenaga kesehatan khususnya perawat) dan tindakan pengobatan itu sendiri. Menurut perawat yang bertugas di ruang rawat anak mengatakan bahwa ada beberapa orang anak yang menolak atau membatalkan untuk rawat inap dengan berbagai alasan salah satunya karena cemas menjalani rawat inap dan memilih untuk rawat jalan. Hasil wawancara dengan perawat ruangan anak RSUD Dr.M.Djamil Padang yang mengatakan bahwa tindakan yang telah dilakukan perawat untuk mengatasi kecemasan anak selama dirawat salah satunya adalah dengan terapi bermain, terapi bermain sudah mulai di terapkan dan sudah memiliki ruangan terapi bermain tetapi belum terlaksana dengan baik dan teratur. Terapi bermain hanya dilakukan bila ada mahasiswa yang praktek dan alat bermain di ruang anak tersebut seadanya.Tujuan penelitian ini adalah untuk mengetahui perbedaan pengaruh terapi bermain mewarnai gambar dengan bermain puzzle terhadap kecemasan anak usia prasekolah di instalasi rawat inap anak RSUP Dr.M.Djamil Padang.

\section{METODE}

Penelitian ini menggunakan desain quasi-eksperimen. Dalam penelitian ini dilihat perbedaan pengaruh terapi bermain mewarnai gambar dengan bermain puzzle terhadap kecemasan anak usia prasekolah (36 tahun) di IRNA Anak RSUP Dr.M.Djamil Padang dengan jumlah 30 responden, 15 responden mendapat terapi bermain mewarnai gambar dan 15 responden mendapatkan terapi bermain puzzle. Penelitian ini dilaksanakan pada bulan Januari hingga Mei 2013. Pengukuran kecemasan dilakukan 2 kali sebelum dan sesudah intervensi. Analisa data univariat dilakukan menggunakan distribusi frekuensi, analisa bivariat menggunakan uji $t$ berpasangan dan uji Independen t-test.

\section{HASIL DAN PEMBAHASAN}

Berdasarkan karakteristik dari 30 responden penelitian yang terdiri dari 15 responden kelompok mewarnai gambar dan 15 responden kelompok bermain puzzle. Proporsi responden berdasarkan umur terbanyak terdapat pada umur 5 tahun dengan jumlah 7 responden $(46,7 \%)$ pada kelompok mewarnai gambar dan umur 6 tahun dengan jumlah 7 responden $(46,7 \%)$ pada kelompok bermain puzzle. Selanjutnya proporsi responden berdasarkan jenis kelamin terbanyak adalah perempuan dengan 10 responden $(66,7 \%)$ pada kelompok mewarnai gambar dan 10 responden $(66,7 \%)$ pada kelompok bermain puzzle. Berdasarkan diagnosa medis pada kedua kelompok terbanyak yaitu penyakit akut dengan jumlah 11 responden $(73,3 \%)$ pada kelompok mewarnai gambar dan 8 responden $(53,3 \%)$ pada kelompok bermain puzzle. 
Tabel 1. Perbedaan Pengaruh Terapi Mewarnai Gambar Dengan Bermain Puzzle Terhadap Kecemasan

\begin{tabular}{lccc}
\hline \multicolumn{1}{c}{ Kelompok } & Mean & $\begin{array}{c}\text { Std. } \\
\text { Deviatio } \\
\mathrm{n}\end{array}$ & $\mathrm{p}$ \\
& & \pm 3.07 & \\
\hline $\begin{array}{l}\text { Kelompok } \\
\text { mewarnai gambar }\end{array}$ & 8.80 & & \\
$\begin{array}{l}\text { Kelompok } \\
\text { bermain puzzle }\end{array}$ & 5.93 & \pm 2.60 & 0,010 \\
\hline
\end{tabular}

Hasil Uji t berpasangan didapatkan $\mathrm{p}$ value $=0,010 \quad(\mathrm{p}<0,05)$, artinya terdapat perbedaan bermakna penurunan skor kecemasan antara kelompok mewarnai gambar yang mendapatkan terapi bermain mewarnai gambar dengan kelompok bermain puzzle yang mendapatkan terapi bermain puzzle. Menurut Supartini (2004), bermain pada anak di rumah sakit tidak hanya akan memberikan rasa senang pada anak, tetapi juga membantu anak mengekspresikan perasaan dan pikiran cemas, takut, sedih, tegang, dan nyeri. Pada beberapa anak yang belum dapat mengespresikan perasaan dan pikiran secara verbal atau pada anak yang kurang mampu mengekspresikannya, permainan menggambar, mewarnai atau melukis akan membantu mengespresikan perasaan tersebut.

Puzzle merupakan permainan yang membutuhkan kesabaran dan ketekunan anak dalam merangkainya. Oleh karena itu lambat laun, mental anak juga terbiasa untuk bersikap tenang, tekun, dan sabar dalam menyelesaikan sesuatu. Kepuasan yang didapat saat ia menyelesaikan puzzle merupakan alah satu pembangkit motivasi untuk mencoba hal-hal yang baru baginya dan membangkitkan rasa percaya diri anak sehingga dapat menambah rasa aman pada anak. Berbeda dengan terapi bermain puzzle, terapi bermain mewarnai gambar memberikan dampak yang positif pada anak. Kegiatan mewarnai dapat memberikan efek rileks pada responden karena aktivitasnya yang mengasyikan, perkenalan anak dengan gambar serta warna yang cocok untuk diberikan pada gambar yang ada berarti memberikan pada anak suatu cara untuk berkomunikasi tanpa menggunakan kata sehingga dapat mengurangi kecemasan pada anak. Anak yang sakit dan dirawat dirumah sakit akan diliputi kecemasan, kegelisahan, kesedihan, kemarahan, kehilangan, kesepian, ketakutan, serta depresi yang justru akan memperberat kondisinya.

Dalam kondisi ini yang dibutuhkan adalah terapi yang dapat memberikan efek rileks, kesenangan sehingga anak yang dirawat akan lebih tenang dan bisa menerima semua bentuk pengobatan dan perawatan yang dilakukan selama di rumah sakit. Dinamika secara psikologis menggambarkan bahwa selama mewarnai anak akan mengekspresikan imajinasinya dalam goresan warna pada gambar sehingga untuk sementara waktu anak akan merasa lebih rileks. Ini sesuai dengan kondisi anak setelah dilakukan terapi bermain mewarnai gambar dimana sebagian besar anak merasa nyaman dan tenang.

Penelitian terkait yang membuktikan pengaruh terapi bermain mewarnai gambar adalah penelitian yang dilakukan Doni Septyana (2013) bahwa Bermain mewarnai gambar mendukung anak merasa bahagia, sehingga menstimulasi saraf-saraf otak (sinaps) untuk saling terhubung, sehingga membentuk sebuah memori baru yang indah akan mengurangi kecemasan selama anak di rawat di rumah sakit.

\section{KESIMPULAN DAN SARAN}

Berdasarkan hasil penelitian ini membuktikan bahwa terapi bermain mewarnai gambar lebih baik dalam menurunkan skor kecemasan dibandingkan dengan terapi bermain puzzle. Diharapkan Agar terapi bermain mewarnai gambar dapat digunakan oleh keluarga kepada anak sebagai terapi non farmakologi dalam mengatasi kecemasan anak prasekolah.

\section{DAFTAR PUSTAKA}

Adriana, D. (2011). Tumbuh kembang dan terapi bermain pada anak. Jakarta : Salemba Medika. 
Nelson. (2000). Ilmu kesehatan anak (Volume 1, Edisi 15). Jakarta : EGC.

Supartini, Yupi. (2004). Konsep dasar keperawatan anak. Jakarta : EGC.

Wijayanti, P. (2009). Faktor-faktor yang berhubungan dengan regresi anak prasekolah saat hospitalisasi di rumah sakit anak dan bunda harapan kita Jakarta. Skripsi.

Wong. (2008). Buku ajar keperawatan pediatric (Volume 1). Jakarta : EGC 